\title{
Penerapan Konsep Pembelajaran Industri 4.0 pada Pendidikan Dasar Desain
}

\author{
Jhon Viter Marpaung \\ Desain Produk, Fakultas Desain dan Industri Kreatif, Universitas Esa Unggul Jakarta \\ e-mail: jhon.viter@esaunggul.ac.id
}

\begin{abstract}
Abstrak-Pada umumnya semua sarana pendukung media pembelajaran diciptakan untuk memberikan kemajuan dan kemudahan, hal itu dibuktikan dengan adanya inovasi dibidang pendidikan dasar desain khususnya. Menerapkan unsur tehnik traditional sketch media pensil dan kertas adalah sesuatu yang mendasar dan harus dikuasai oleh setiap siswa, hal ini sangat penting dikarenakan bersifat fundamental/mendasar yang diterima oleh setiap siswa. Dalam pelaksanaannya, pembelajaran keilmuan dasar desain sangat berkembang dan menyesuaikan dengan kemajuan teknologi digital. Desain menjadi sangat aplikatif ketika berdampingan dengan teknologi, menciptakan suatu bentuk atau rancangan yang sangat luas dan tidak terbatas. Hal ini sangat penting karna untuk menjawab kebutuhan akan kemajuan jaman yang semakin canggih dan praktis, di era industri 4.0 ini dituntut untuk terus ber inovasi didalam media pendidikan dasar pembelajaran kedalam media digital yang lebih praktis dan efisien didukung oleh aplikasi dan hardware untuk menjawab kebutuhan industri dan menghasilkan lulusan yang mampu bersaing di dalam industri dan global. Pentingnya penerapan IPTEK kedalam pendidikan dasar desain untuk terus dikembangkan melalui penerapan metode dan teknik yang disesuaikan berdasarkan kebutuhan Pendidikan Dasar Desain
\end{abstract}

Kata kunci-Pendidikan dasar desain, Media digital, digital sketch, industri 4.0.

\begin{abstract}
In general, all means of supporting learning media are created to provide progress and ease, this is evidenced by the innovation in the field of basic education in particular design. Applying elements of traditional sketch and paper media techniques is something that is basic and must be mastered by every student, this is very important because it is fundamental / accepted by every student. In practice, basic scientific learning design is highly developed and adapts to the advancement of digital technology. Design becomes very applicable when it coexists with technology, creating a form or design that is very broad and unlimited. This is very important because to answer the need for an increasingly sophisticated and practical era, in the industrial era 4.0 it is demanded to continue to innovate in the media of basic education learning into a more practical and efficient digital media supported by applications and hardware to answer the needs of the industry and produce graduates who are able to compete in industry and globally. The importance of the application of science and technology into design basic education to continue to be developed through the application of methods and techniques that are tailored to the needs of Basic Design Education
\end{abstract}

Keywords-Basic design education, digital media, digital sketch, industry 4.0, Product Design

\section{PENDAHULUAN}

Metode dan penerapan aplikasi pembelajaran semakin luas dan berkembang, hal ini terbukti dengan adanya peran teknologi untuk semakin memudahkan kegiatan dan pengembangan tingkat kreativitas siswa terus berkembang didunia pendidikan khususnya. Seperti yang tertera didalam UU No.20 tahun 2003 Pendidikan adalah usaha dasar dan terencana untuk mewujudkan suasana belajar dan proses pembelajaran agar peserta didik secara aktif mengembangkan potensi dirinya untuk memiliki kekuatan spiritual keagamaan, pengendalian diri, kepribadian, kecerdasan, akhlak mulia, serta keterampilan, yang diperlukan dirinya, masyarakat, dan Negara [1], [2], dan [3]. Peran pendidikan secara mendasar memiliki tugas untuk mendidik bangsa. Pendidikan merupakan faktor penting bagi masyarakat, demi maju mundurnya kualitas masyarakat atau bangsa sangat bergantung pada pendidikan yang ada pada rakyat bangsa tersebut meningkatkan kualitas pembelajaran dalam pendidikan sangatlah baik, guna memberikan keleluasaan siswa didik untuk mengembangkan tingkat kretifitas dan pembelajaran akan penerapan teknologi didalam pembelajarannya. Teknologi juga dimanfaatkan dalam penyelenggaraan pendidikan. Teknologi pendidikan akan membantu semua aspek pendidikan dalam upaya meningkatkan kualitas pelayanan dan kwalitas produk yang dihasilkan. Produk dalam ranah pendidikan yaitu siswa yang berkualitas dan memiliki daya saing.

Terobosan teknologi di bidang mikro-elektronika, bio teknologi, telekomunikasi, komputer, internet, dan robotik telah mengubah secara mendasar cara-cara kita mengembangkan dan mentransformasikan teknologi ke dalam sektor produksi yang menghasilkan barang dan jasa dengan teknologi tinggi [4], [5], [6], dan [7]. Kemajuan teknologi juga akan berdampak dengan keragaman media yang digunakan oleh para tenaga pendidik. Teknologi akan membantu para guru dalam pembuatan media. Media akan lebih menarik dan variatif apabila guru mampu memanfaatkan teknologi yang ada. Namun guru kurang mampu menguasai teknologi yang tersedia. Cenderung guru yang berusia lanjut, tidak memahami bagaimana peran, fungsi dan manfaat dari teknologi dan media, justru tetap mempertahankan gaya konvensional tanpa menyelipkan unsure kemajuan teknologi di dalamnya. Hal inilah yang melatarbelakangi penyusunan makalah ini yang membahas tentang peran teknologi dan media dalam belajar 


\section{METODE}

Metode yang diterapkan dalam penelitian ini adalah menerapkan metode kualitatif. Dengan tujuan untuk mendapatkan esensi dari instrument penelitian ini. dikarenakan peneliti ingin mendapatkan data yang mendalam serta mengetahui secara lebih jelas mengenai objek yang diteliti. Oleh karena itu, peneliti melakukan penelitian secara langsung dan terlibat sebagai instrumen penelitian. Metode penelitian yang digunakan dalam penulisan ini adalah metode penelitian kualitatif deskriptif, dengan pendekatan fenomenologis. Metode kualitatif menggunakan istilah "autentisitas" dari pada validitas . Autentisitas berarti memberikan deskripsi, keterangan, informasi (account) yang adil dan jujur. Hasil yang diperoleh dijamin interpretasinya dengan tepat. Metode kualitatif beranggapan bahwa manusia selalu dalam proses menjadi dan berkembang, sehingga berlaku juga bagi setiap ilmu kemanusiaan yang selalu berada dalam proses pengembangan. Penelitian ini juga menekankan pada permahaman mengenai masalah-masalah dalam kehidupan sosial berdasarkan kondisi realitas yang bersifat subjektif dan berdimensi banyak [8], [9], [10], dan [11]. Peneliti juga akan berinteraksi dengan fakta yang diteliti sehingga lebih bersifat subjektif (tidak bebas nilai). Penelitian ini menggunakan pendekatan fenomenologi, sehingga dalam pengumpulan data peneliti menggunakan metode, antara lain:

1. Metode Observasi, metode dimana peneliti mengamati langsung obyek yang di teliti.

2. Metode Eksperimental, metode ini memberikan kesembatan bagi peneliti untuk mengalami sendiri, mengikuti proses, mengamati obyek, menganalisis, membuktikan dan menarik kesimpulan sendiri mengenai proses obyek yang dilakukan .

3. Dokumentasi, sebuah pencarian, penyelidikan, pengumpulan, pengawetan, penguasaan, pemakaian dan penyediaan dokumen. Dokumentasi ini digunakan untuk mendapatkan keterangan dan penerangan pengetahuan dan sebagai bukti. Penelitian hanya dilakukan dalam lingkup kajian perkembangan IPTEK didalam perkembangan teknologi pendukung pendidikan, yang diterapkan kedalam pembelajaran desain. Dalam penerapannya, dalam pencarian data melakukan hasil analisis langsung dengan datang keberbagai Exhibition teknologi yang di peruntukan untuk kemajuan dalam pembelajaran. Salah satunya dengan Metode Observasi, metode dimana peneliti mengamati langsung obyek yang di teliti. Sehingga peneliti mendapatkan pembaharuan serta informasi yang valid dari perkembangan IPTEK yang sedang berkembang untuk memajukan pembelajaran di Indonesia khususnya.

\section{HASIL DAN PEMBAHASAN}

\section{Konsep Teknologi}

Manusia pada awalnya tidak mengenal konsep teknologi. Kehadiran manusia purba pada masa pra sejarah, hanya mengenal teknologi sebagai alat bantunya dalam mencari makan, alat bantu dalam berburu, serta mengolah makanan. Alat bantu yang mereka gunakan sangatlah sederhana, terbuat dari bambu, kayu, batu, dan bahan sederhana lain yang mudah mereka jumpai di alam bebas. Misalnya untuk membuat perapian, ia memanfaatkan bebatuan yang dapat memunculkan percikan api [12], [13], dan [14].

Pada awalnya teknologi berkembang secara lambat. Namun seiring dengan kemajuan tingkat kebudayaan dan peradaban manusia perkembangan teknologi berkembang dengan cepat. Semakin maju kebudayaannya, semakin berkembang teknologinya karena teknologi merupakan perkembangan dari kebudayaan yang maju dengan pesat.

Secara harfiah teknologi berasal dari bahasa Yunani, yaitu "tecnologia" yang berarti pembahasan sistematik mengenai seluruh seni dan kerajinan. Istilah tersebut memiliki akar kata "techne" dalam bahasa Yunani kuno berarti seni (art), atau kerajinan (craft). Dari makna harfiah tersebut, teknologi dalam bahasa Yunani kuno dapat didefinisikan sebagai seni memproduksi alat-alat produksi dan menggunakannya. Definisi tersebut kemudian berkembang menjadi penggunaan ilmu pengetahuan sesuai dengan kebutuhan manusia. Teknologi dapat pula dimaknai sebagai "pengetahuan mengenai bagaimana membuat sesuatu (knowhow of making things) atau "bagaimana melakukan sesuatu" (know-how of doing things), dalam arti kemampuan untuk mengerjakan sesuatu dengan nilai yang tinggi, baik nilai manfaat maupun nilai jualnya [15] dan [16]..

Dalam konsep yang pragmatis dengan kemungkinan berlaku secara akademis dapatlah dikatakan, bahwa ilmu pengetahuan (body of knowledge), dan teknologi sebagai suatu seni (state of art) yang mengandung pengertian berhubungan dengan proses produksi; menyangkut cara bagaimana berbagai sumber, tanah, modal, tenaga kerja, dan keterampilan dikombinasikan untuk merealisasikan tujuan produksi. "secara konvensional mencakup penguasaan dunia fisik dan biologis, tetapi secara luas juga meliputi teknologi sosial, terutama teknologi sosial pembangunan sehingga teknologi itu adalah metode sistematis untuk mencapai setiap tujuan Insani"

\section{Janji Teknologi}

Suatu hal yang perlu mendapat perhatian khusus adalah bahwa setiap perkembangan teknologi selalu menjanjikan kemudahan, efisiensi, serta peningkatan produktivitas. Memang pada awalnya teknologi diciptakan untuk mempermudah manusia untuk memenuhi segala kebutuhan hidupnya. Berikut ini ada beberapa hal yang dijanjikan teknologi:

1) Teknologi menjanjikan perubahan Setiap penemuan baru akan melahirkan berbagai perubahan dalam suatu masyarakat. Ibarat sebuah subsistem, kehadiran teknologi baru sebagai subsistem baru dalam masyarakat akan membawa konsekuensi, subsistem lain dalam sistem tersebut mau tidak mau harus menyesuaikan diri akibat kehadiran teknologi tersebut. Teknologi pasti akan mengubah pola aktifitas keseharian individu. Kehadiran televisi di rumah misalnya, akan menyebabkan munculnya agenda baru setiap hari, ada jadwal menonton acara favorit yang sebelumnya tidak ada. Jadwal mandi, jadwal makan, jadwal minum kopi, jadwal membersihkan rumah, jadwal belajar, jadwal kencan, sampai jadwal tidur akan disesuaikan dengan jadwal acara di televisi. Bahkan susunan perabotan di rumah, meja, kursi, lemari, 38 
Jurnal Pembangunan Pendidikan: Fondasi dan Aplikasi Volume 2, Nomor 1, 2014 Jurnal Pembangunan dan Pendidikan: Fondasi dan Aplikasi karpet, sofa, akan disesuaikan dengan di mana kita meletakkan televisi.

2) Teknologi menjanjikan kemajuan Teknologi merupakan simbol kemajuan. Siapa saja yang mampu mengakses teknologi, maka ia akan mengalami sedikit atau banyak kemajuan ke arah entah dalam bentuk apa pun. Seseorang tidak akan ketinggalan informasi mana kala ia menggenggam sebuah teknologi. Teknologi telah mempengaruhi gaya hidup, dan bahkan teknologi juga telah menjadi gaya hidup itu sendiri.

3).Teknologi menjanjikan kemudahan Teknologi memang diciptakan untuk memberikan kemudahan bagi individu. Orang tidak perlu susah-susah untuk menghubungi sanak keluarganya di luar kota, bahkan di luar negeri; mereka cukup menekan beberapa nomor melalui hanphone. Orang tidak perlu mengantri di depan petugas teller bank untuk melakukan berbagai transaksi, kita cukup masuk ke ruang ATM dan kita dapat melakukan berbagai transaksi menggunakan mesin tersebut, mulai mengambil uang, membayar tagihan listrik, air, telepon, membeli pulsa, membeli tiket kereta api, pesawat, kapal, membayar SPP, mengirim uang ke rekening lain, sampai membayar tagihan kredit. Ketika kita lapar, kita cukup menekan beberapa nomor delivery order, kemudian dalam beberapa menit, petugas pengantar makanan sampai di depan pintu rumah kita. Kita dapat memanfaatkan pesawat terbang untuk melakukan perjalanan jauh dalam waktu singkat; kita tidak perlu bersusah payah naik ke lantai yang lebih tinggi di sebuah gedung bertingkat, kita cukup memanfaatkan lift atau eskalator.

4) Teknologi menjanjikan peningkatan produktivitas Perusahaan besar banyak memanfaatkan teknologi untuk alasan efisiensi dan peningkatan produktivitas daripada harus mempekerjakan tenaga kerja manusia yang memakan banyak anggaran untuk menggaji mereka. Teknologi juga dapat meningkatkan keuntungan perusahaan dengan berlipat ganda. Teknologi juga dapat dimanfaatkan sebagai alat kontrol untuk mengevaluasi kinerja seseorang. Teknologi finger print (sistem presensi dengan memanfaatkan sidik jari) misalnya, akan dapat mengontrol tingkat kehadiran karyawan di kantor.

5) Teknologi menjanjikan kecepatan Berbagai pekerjaan akan dapat diselesaikan dengan cepat manakala kita memanfaatkan teknologi. Keberadaan komputer akan membantu mempercepat pekerjaan di kantor, mempercepat pembukuan, teknologi juga akan mempercepat proses pengiriman dokumen, surat atau file, serta barang. Memasak nasi akan lebih cepat jika menggunakan rice cooker. Semua pekerjaan dan setiap kesulitan akan teratasi dengan teknologi.

6) Teknologi menjanjikan popularitas manusia dengan mudahnya muncul di layar kaca melalui internet.

\section{Masyarakat Digital}

Era modern diidentikkan dengan era masyarakat digital. Setiap aktivitas manusia akan digerakkan melalui serangkaian teknologi digital. Teknologi ini dioperasikan dengan menekan beberapa digit (angka) yang di susun dengan berbagai urutan. Relasi yang terbangun di antara individu adalah relasi pertukaran digital, setiap manusia hanya melakukan serangkaian transaksi atau interaksi melalui simbol-simbol digital. Transaksi perdagangan, komunikasi, semuanya digerakkan Kemajuan Teknologi dan Pola Hidup Manusia (Gambar 1) .

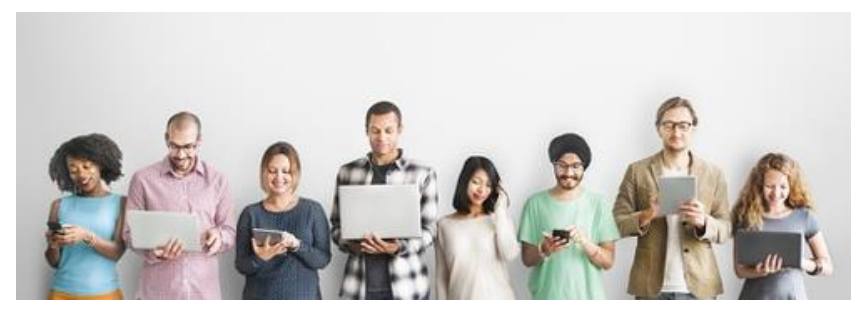

Gambar 1. Masyarakat Digital

sumber : https://tirto.id/bersatuindonesiaku-mengedukasi-masyarakatdigital-lawan-terorisme-cKrb

Setiap individu akan memiliki identitas digital yang mampu mengenali siapa dirinya, setiap manusia sudah diberi nomor urut: melalui nomor identitas (e-KTP), nomor handphone, nomor telepon, nomor rekening bank, nomor ATM, nomor rekening listrik, rekening telepon, rekening air, PIN (Personal Identification Number) ATM, semuanya menggunakan sistem digital. Interaksi antarmanusia digerakkan dengan teknologi serba digital: komputer, internet, mesin ATM, telepon, handphone, dan sebagainya, semuanya digerakkan secara digital. Kita dapat membeli sesuatu hanya dengan menggesek kartu ATM dan menekan beberapa nomor PIN, demikian halnya untuk membayar tagihan kamar hotel, membeli tiket, dan sebagainya. Pengiriman uang dapat dilakukan dalam hitungan detik hanya dengan menekan beberapa digit nilai uang yang akan dikirim dan beberapa digit nomor rekening tujuan. Bukan uang yang dikirim, melainkan hanya sederet angka yang berpindah dari rekening satu ke rekening yang lain

\section{Pengaruh Kemajuan Teknologi}

Bidang Sosial Budaya Beberapa bentuk perubahan perilaku sosial budaya akibat teknologi antara lain sebagai berikut:

1) Perbedaan kepribadian pria dan wanita. Banyak pakar yang berpendapat bahwa kini semakin besar porsi wanita yang memegang posisi sebagai pemimpin, baik dalam dunia pemerintahan maupun dalam dunia bisnis. Bahkan perubahan perilaku ke arah perilaku yang sebelumnya merupakan pekerjaan pria semakin menonjol.

2) Meningkatnya rasa percaya diri. Kemajuan ekonomi di negara-negara Asia melahirkan fenomena yang menarik. Perkembangan dan kemajuan ekonomi telah meningkatkan rasa percaya diri dan ketahanan diri sebagai suatu bangsa akan semakin kokoh. Bangsabangsa Barat tidak lagi dapat melecehkan bangsabangsa Asia.

3) Tekanan, kompetisi yang tajam di berbagai aspek kehidupan sebagai konsekuensi globalisasi, akan melahirkan generasi yang disiplin, tekun dan pekerja keras. 
Kondisi sekarang ini manusia sering dipandang menjadi objek teknik dan harus selalu menyesuaikan diri dengan teknik yang ada.

\section{Perkembangan Ilmu Desain Terhadap Teknologi}

Di era digital perkembangan fasilitas dan layanan akan media tooling terus ber inovasi. Sebagai contoh produk Wacom Cintiq, suatu alat bantu digital untuk mempermudah dalam proses melakukan kreatifitas sketsa brainstorming hingga melakukan finalisasi sebuah rancangan dalam bentuk visual sketsa suatu produk dapat dilakukan dengan mudah. Hardware yang ter integrasi dengan dukungan software seperti Sketchbookpro dari Alias, Photoshop dari Adobe, dan aplikasi pendukung 2D lainnya untuk melakukan proses developing ideas, sehingga penggunaan kertas dapat dikurangi dan prosesnya praktis dan efisien. Pendidikan dasar desain sebagai bentuk fundamental pembelajaran desain yang memiliki cirikhas dan budaya tradisional yang terus dilakukan seperti penerapan proses sketsa 2D dilakukan melalui media pensil dan kertas, namun kini di era evolusi industri 4.0 kegiatan sketsa pada media itu sudah tidak menjadi "titik berat" ketergantungan dalam media pembelajaran didalam melakukan pembelajaran hal ini disebabkan sudah tersedianya faktor pendukung media teknologi dalam melakukan kegiatan sketsa (Gambar 2).

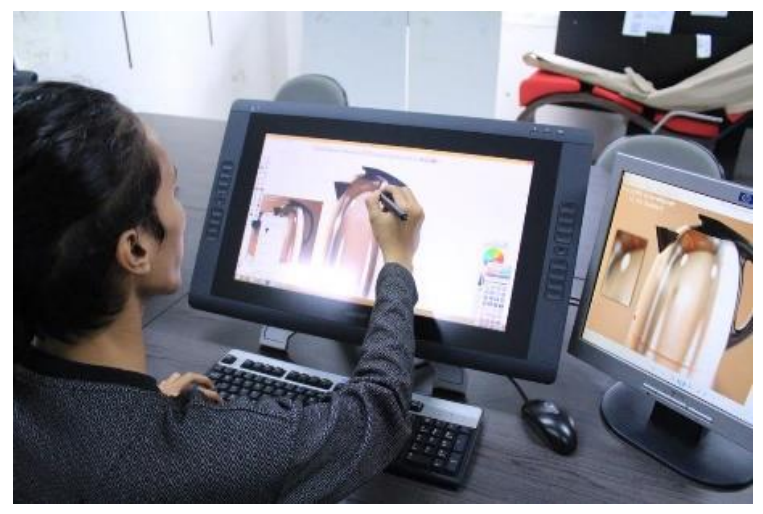

Gambar 2. Wacom Cintiq

(Sumber :https://www.esaunggul.ac.id/fasilitas-kampus/?lang=en)

Inovasi teknologi yang berperan didalam pendidikan desain khususnya sangat berpotensi untuk terus bisa dikembangkan, lain halnya dengan pembelajaran mengenai pengetahuan dan proses pembuatan sebuah skala model sebagai bentuk suatu visualisasi kedalam bentuk 3D hasil dari visualiasi 2D. Material yang digunakan seperti plastik maket, plastisin, ataupun clay modeling yang digunakan sebagai media pembuatan sebuah model secara manual oleh tangan, kini digantikan dengan penerapan digital kedalam media 3D printing yang lebih cepat dan presisi, jika dinilai dari sisi efisiensi menjadi jauh lebih cepat dan memiliki tingkat presisi yang tinggi. Kemajuan ini dipimpin oleh munculnya kecerdasan buatan, robotika, internet, kendaraan otonom, bio dan nanoteknologi, 3D Printing , Pengetahuan akan material, komputasi kuantum dan energy penyimpanan. Pendidikan Industri 4.0 adalah sebuah respons terhadap kebutuhan industri 4.0 di mana manusia dan teknologi diselaraskan untuk memungkinkan sesuatu hal yang baru (Gambar 3).
Revolusi Industri 4.0 adalah sebuah revolusi fundamental yang perlu dihadapi dengan persiapan yang matang, karena menuntut berbagai kemampuan dasar yang belum dituntut oleh pasar tenaga kerja saat ini.

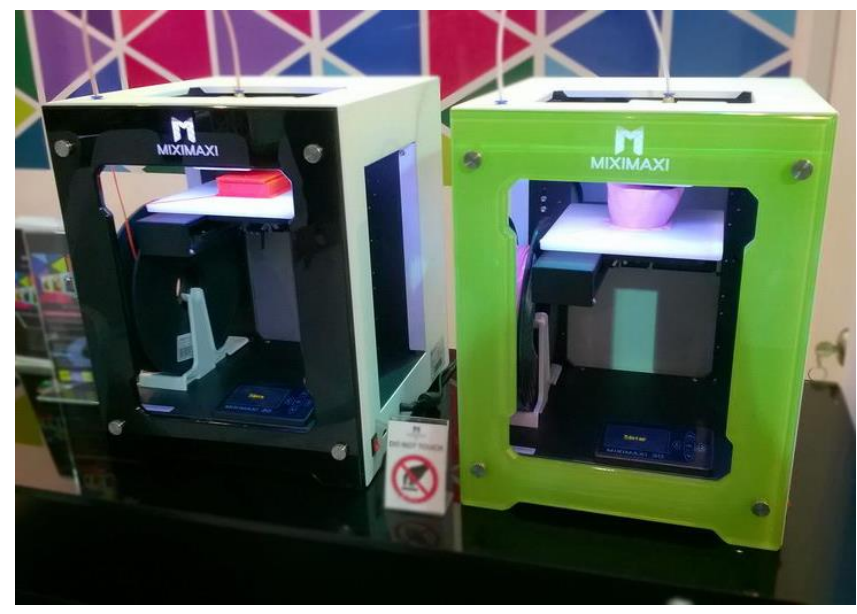

Gambar 3. 3D Printer dari Miximaxi

Penerapan konsep pembelajaran industri 4.0 yang disesuaikan dengan pendidikan dasar desain menjadi lebih produktif dan memiliki dukungan kreatifitas yang luas, didukung dengan media informasi yang disebut dengan Teknologi Informasi dan Komunikasi (TIK).

Sarana dan prasarana, merupakan bagian dari sebuah fasilitas yang menunjang didalam sebuah proses pembelajaran. Sebagai contoh penerapan Wifi pada suatu universitas, mahasiswa diberikan pelayanan Internet sebagai media komunikasi dan informasi untuk mempermudah menjelajah dalam memenuhi kebutuhan informasi terkait dengan materi perkuliahan, Penelitian, dan pengabdian masyakat. Media E-learning yang memudahkan proses pembelajaran tanpa batas yang mampu diakses dimanapun dan kapanpun. e-Learning menawarkan peluang besar untuk pembelajaran jarak jauh dan mandiri.

Dalam pembelajaran dasar desain penting adanya penyerapan teknologi didalam pengaplikasian metode dan teknik yang digunakan. Pengetahuan proses dan materialah yang paling terpenting, sehingga siswa mampu untuk memprioritaskan solusi apa yang akan digunakan untuk menerapkan penggunaan teknologi pendukung yang tepat. Teknologi tidak dapat dipisahkan dengan kehidupan manusia, sehingga didalam fenoma tersebut teknologi selalu hidup berdampingan dengan inovasi dan kemajuan teknologi demi kelangsungan hidup manusia. Begitupun keberadaan didalam dunia pendidikan khususnya pendidikan desain.

Demikian juga dengan Virtual Reality merupakan sebuah inovasi teknologi terbaru yang dikembangkan untuk memungkinkan seseorang melakukan suatu interaksi terhadap suatu objek grafis dengan visualisasi 3D atau gambar berhologram. Teknologi ini mampu memberikan sebuah pengalaman baru bagi penggunanya, karena pengguna seolah-olah bisa menyentuh objek tersebut secara langsung. Jadi sederhananya, Virtual Reality adalah tampilan gambar tiga dimensi yang terlihat seperti nyata yang diciptakan dengan bantuan perangkat komputer ataupun juga beberapa perangkat tertentu. Dengan teknologi ini, pengguna juga dapat merasakan berada dunia nyata, padahal 
sebenarnya mereka hanya berada di dunia virtual atau dunia maya. Untuk mendukung jalannya teknologi Virtual Reality ini, biasanya pengguna juga bisa menggunakan beberapa perangkat yang canggih berupa helm atau kacamata, headset, sarung tangan dan walker (Gambar 4).

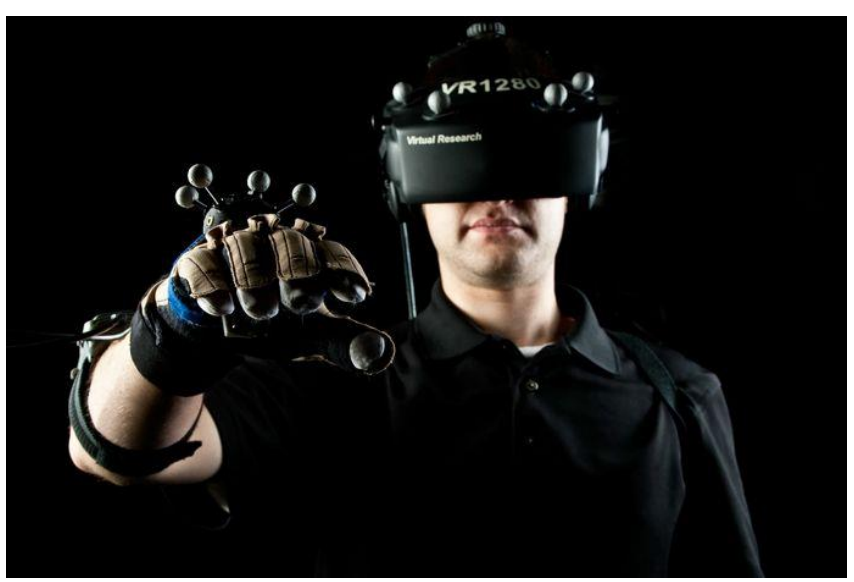

Gambar 4. Virtual Reality.

Virtual Reality saat ini semakin modern, terutama di abad ke 21. Di tahun 2016, ada sedikitnya 230 perusahaan yang mengembangkan produk VR, seperti Facebook, Google, HTC, Sony, dan lain-lainnya. Pada awalnya, VR tertuang dalam bentuk karya sebuah lukisan panjang yang menceritakan tentang suasana perang. Saat ini, VR mengalami perkembangan yang pesat dengan masuknya perangkat-perangkat VR dengan fitur fitur canggih seperti Oculus Rift, HTC Vive, Playstation VR, dan merk lainnya. Perkembangan VR lebih diarahkan kepada tujuan untuk meningkatkan keimersifan yang dirasakan oleh user. Namun, VR pada zaman sekarang masih kurang diminati oleh masyarakat karena adanya kekurangan teknis seperti, representasi gerakan user di layar yang tidak terintegrasi dengan baik dan nyata, ke-efektifan penggunaan kontroler, harga yang tidak sesuai dengan jangkauan masyarakat, dan hal lainnya.

\section{Teknologi pada VR}

\section{Sensory-immersion VR,}

Yaitu perangkat antar muka (interface) yang melibatkan secara langsung sensasi inderawi seperti headmounted display (helm VR), data glove (sarung tangan), dan body suit (rompi VR). Helm dengan penutup mata (headmounted display) memberikan gambaran perspektif yang berbeda tentang benda yang dilihat. Begitu kepala digerakkan, gambar-gambar akan bergerak demikian cepat berubah sahingga kita akan merasa seperti membuat perubahan-perubahan ini dengan gerakan kepala. Manusia adalah penyebab dan bukan sebagai penerima akibat.

Head mounted display (HMD) menggunakan teknik yang disebut dengan streoscopy yang menempatkan gambar berbeda pada setiap mata. Head tracking adalah disaat kita menggunakan VR headset, gambar yang berada tepat pada pandangan selagi kita melihat keatas, kebawah dan melihat ke kiri dan kanan, Sistem tersebut disebut dengan 6DoF (Six degrees of freedom).

\section{Projection VR,}

Mencakup interaksi dengan proyeksi obyek pada layar lebar yang merepresentasikan lingkungan virtual buatan seperti CAVE (Cave Automatic

Virtual Environment) atau Responsive Workbench

\section{Simulator $V R$,}

Mencakup lingkungan buatan fisik yang bertujuan untuk lebih mendekatkan realita lingkungan kepada pengguna. Pada industri otomotif, umumnya mereka membangun sebuah mock up kabin penumpang lengkap dengan monitor yang berfungsi sebagai - kaca depan yang dihubungkan dengan perangkat VR sehingga secara dinamis mock up mampu memberikan efek natural seperti getaran atau goncangan.

\section{Desktop VR,}

Mencakup perangkat keras yang menunjukkan proses pemodelan VR di layar komputer.

\section{Peluang pengembangan}

Di masa depan, VR bisa saja menjadi standar penunjuk perkembangan teknologi di dunia. Headset VR akan menjadi wireless, dan bisa berjalan tanpa harus didukung oleh komputer (PC-driven VR)dan dapat disinkronkan dengan smartphone sehingga menghasilkan high level graphic pada lensa VR tersebut. Selain itu, controller VR bisa menjadi multifungsi. Jika misalnya, pedang dalam dunia virtual maka controllernya harus berbentuk seperti pedang dan pistol dalam dunia virtual, harus dibuatkan controller berbeda yang berbentuk seperti pistol. Maka di masa depan, bentuk controller bisa menjadi multifungsi tanpa harus menyerupai bentuk representasinya. Misalnya, sebuah controller bisa direpresentasikan menjadi pistol, pedang, dan benda lainnya di dalam dunia virtual tersebut.

Lalu, tidak diperlukan sebuah HMD dengan ukuran besar untuk menambah keimersifan sebuah perangkat, tapi hanya dengan alat seminim dan se-efisien mungkin serta controller yang bisa saja berupa sebuah chip yang dipasangkan pada user, dapat memberikan kesan fully immersive pada user.

Helm atau kacamata berfungsi untuk memvisualisasikan tampilan gambar agar pengguna dapat melihat perspektif gambar terlihat lebih dekat dan lebih nyata. Headset berfungsi memberikan efek-efek suara yang keluar kepada pengguna dengan lebih jelas, sehingga akan membuat pengguna seperti didalam suasana yang nyata. Sarung tangan dan walker berfungsi sebagai media penghubung interaksi tangan dan kaki pengguna dengan dunia virtual yang diciptakan oleh Virtual Reality, sehingga pengguna bisa merasakan pengalaman menyentuh, merasakan benda-benda yang muncul secara virtual dan berjalan di dunia maya seperti nyata. Elemen-elemen di dalam Virtual Reality sendiri terbagi dalam beberapa bagian, yaitu:

a. Virtual World: Merupakan sebuah konten grafis maupun hologram yang mampu menciptakan dunia secara virtual dalam bentuk screen play.

b. Sensory Feedback: Merupakan media untuk menyampaikan serangkaian informasi dari virtual world menuju ke indera pengguna. Beberapa informasi yang 
disampaikan diantaranya penglihatan, pendengaran dan juga sentuhan.

c. Interactivity: Berfungsi untuk merespon segala gerakan dan sentuhan pengguna. Sehingga pengguna dapat berinteraksi secara langsung dengan berbagai objek di dalam dunia virtual.

d. Immersion: Merupakan elemen yang bisa dikatakan sangat penting di dalam teknologi Virtual Reality. Karena bagian ini dapat membuat dapat mempengaruhi pengguna baik secara fisik maupun mental. Sehingga pengguna merasa jika dirinya berada di sebuah lingkungan yang nyata, padahal pengguna hanya berada dalam dunia virtual dan tidak terjadi secara nyata.

Teknologi Virtual Reality sudah banyak digunakan dalam berbagai bidang. Seperti bidang kedokteran, penerbangan, militer, bahkan juga digunakan sebagai perangkat pendukung untuk bermain game (Gambar 5).

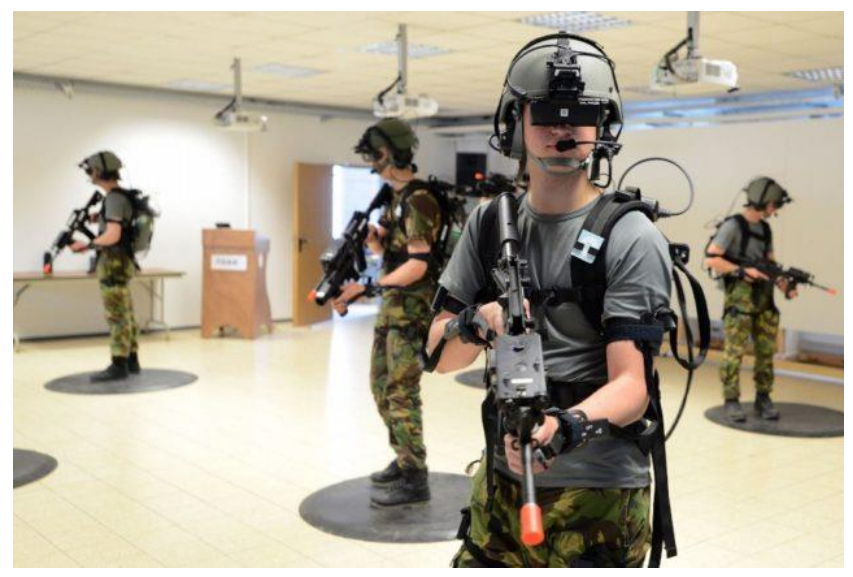

Gambar 5. Virtual Reality dalam Simulasi Militer. (Sumber: www.vrlife.news)

Bidang lain yang dapat menggunakan teknologi Virtual Reality adalah bidang militer. Sama seperti bidang kesehatan, para pekerja di bidang militer membutuhkan waktu latihan yang banyak, selain itu mereka juga dituntut untuk presisi dalam melakukan setiap pekerjaan mereka. Dengan menggunakan Virtual Reality, para pekerja militer dapat mensimulasikan kendaraan tempur mereka, sehingga apabila pengguna melakukan kesalahan dalam mengoperasikan kendaraan pihak militer tidak perlu menanggung biaya yang besar untuk memperbaiki kendaraan mereka. Selain itu Virtual Reality juga dapat digunakan untuk mensimulasikan kondisi-kondisi berbahaya yang membutuhkan pelatihan dalam mengambil keputusan, seperti penjinakan bom, pelepasan sandera, dan lain-lain. Dengan menggunakan Virtual Reality para pekerja militer dapat mensimulasikan bagaimana kondisi-kondisi darurat tanpa harus menyiapkan setting lokasi yang cukup merepotkan.

Penerapan VR kedalam pembelajaran media merancang sebuah produk menjadi lebih mudah dan cepat untuk membangun sebuah visual secara realtime bentuk 3D yang dapat langsung dievaluasi dan dikembangkan secara terus menerus. Media ini sudah diterapkan di industri besar terkemuka dunia. Selain mudah juga mampu mengurangi potensi human error dalam kategori produksi atau yang kita kenal dalam istilah pembuatan skala modelnya/prototyping.
Pengertian pembelajaran industri 4.0

Revolusi Industri 4.0 mendorong kurikulum pendidikan tinggi agar sesuai dengan dinamika digital, internet of thing, Artificial Intelligence, bioteknologi, serta perkembangan pesat lainnya. Jika tidak disesuaikan, lulusan perguruan tinggi tidak akan sesuai untuk menjadi pemikir dan pekerja di era ini. Revolusi Industri 4.0 mendorong kurikulum pendidikan tinggi agar sesuai dengan dinamika digital, internet of thing, Artificial Intelligence, bioteknologi, serta perkembangan pesat lainnya. Jika tidak disesuaikan, lulusan perguruan tinggi tidak akan sesuai untuk menjadi pemikir dan pekerja di era ini. Perkembangan pendidikan di dunia tidak lepas dari adanya perkembangan dari revolusi industri yang terjadi di dunia, karena secara tidak langsung perubahan tatanan ekonomi turut merubah tatanan pendidikan di suatu negara (Gambar 6).

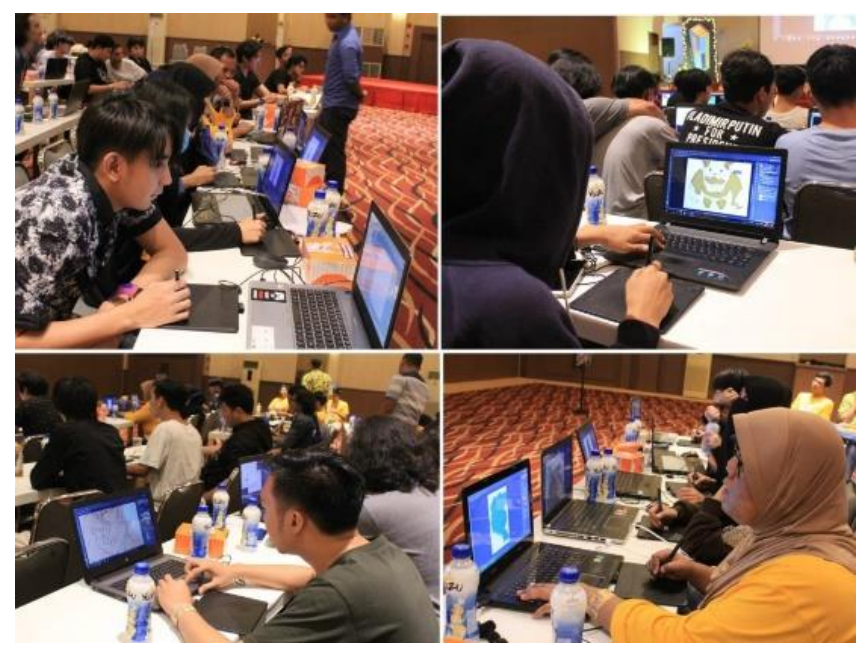

Gambar 6. Kelas workshop Digial Imaging

(Sumber : https://www.esaunggul.ac.id/unjuk-gigi-anak-desain-di-intervalfrequency-2018/)

Pengembangan pendidikan di dunia tidak lepas dari adanya perkembangan dari revolusi industri yang terjadi di dunia, karena secara tidak langsung perubahan tatanan ekonomi turut merubah tatanan pendidikan di suatu negara. Kemajuan teknologi selalu disertai dengan kebutuhan dan penerapan yang disesuaikan dengan sebuah aspek atau bidang yang akan dikembangkan. Metode sebuah pembelajaran beserta tekniknya mengalami perkembangan, khususnya didalam meningkatkan kreatifitas para siswa untuk mencari sebuah solusi sebuah permasalahan melalui sebuah perancangan produk yang mampu memberikan jawaban atas permasalahan tersebut.

\section{Penerapan fungsi teknologi kedalam Media Pembelajaran}

Teknologi memiliki peran yang sangat penting bagi kehidupan manusia didalam melakukan aktifitasnya, banyak sekali inovasi yang dirancang dan dikembangkan untuk mampu memberikan solusi bagi manusia. Perancangan ciptakan berdasarkan kebutuhan manusia, dan secara teknisnya disesuaikan dengan bidang dan peran teknologi tersebut diberbagai aspek kehidupan (Gambar 7).

Manusia dan teknologi tidak bisa dipisahkan hal ini dikarenakan kemudahan dan kecanggihan yang dimiliki 
sangat memiliki peran penting atas kehidupan manusia sebagai mahluk sosial yang selalu berinteraksi. Begitupun halnya dengan kebutuhan didalam pendidikan, pembelajaran menjadi sangat menyenangkan, memberikan keleluasaan didalam menciptakan nilai-nilai kreatifitas, melakukan pengembangan menjadi sebuah inovasi baru berupa konsep perancangan sebuah produk yang dihasilkan. Kemudahan dan presisi yang diberikan oleh teknologi sangat baik, seperti dalam kegiatan sebuah pendidikan desain dalam merancang sebuah produk misalnya, pembuatan model sebuah transportasi berkonsep electric car. Dengan menggunakan 3D printing menjadi sangat mudah dan presisi, melakukan tugasnya dengan cepat dan tepat, serta didukung oleh berbagai macam material yang disesuaikan oleh kebutuhan siswa dalam merancang sebuah visual $3 \mathrm{~d}$ model konsep desain berupa contoh model.

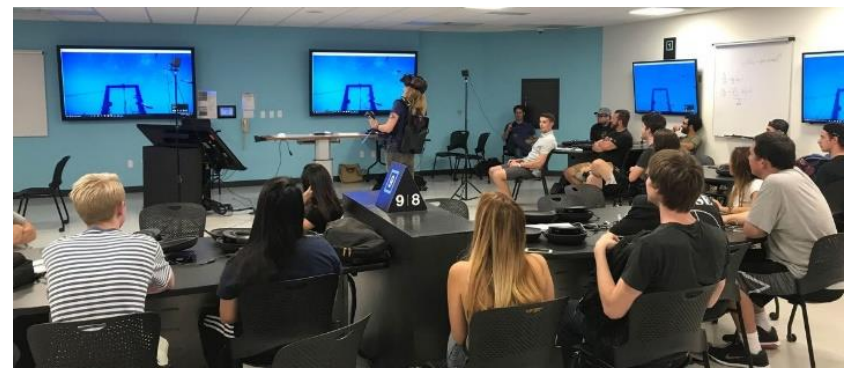

Gambar 7. Penerapan teknologi paa proses pembelajaran (Sumber : https://monsterar.net/2019/07/05/penerapan-ar-di-bidangpendidikan/)

Contoh ini menjadikan sebuah ilustrasi betapa berpotensinya fungsi teknologi bila diterapkan kedalam media pembelajaran, dan sudah seharusnya pemerintah mendukung untuk menerapkan fungsi teknologi kedalam pendidikan sebagai acuan standar yang harus ditetapkan secara menyeluruh, sehingga Sumber Daya Manusia kita bisa berkembang dan mampu beradaptasi dengan kemajuan dan inovasi teknologi.

\section{KESIMPULAN}

Penerapan teknologi kedalam media pembelajaran memberikan sebuah tantangan dan inovasi terhadap pendidikan di Indonesia. Hal ini perlu adanya konsistensi menyeluruh oleh instansi pemerintah untuk terus mensosialisasikan kepada pihak yang berwewenang khususnya dibidang pendidikan. Secara khusus, pendidikan dasar desain sangatlah berpotensi bila penerapan teknologi diterapkan kedalam media pembelajaran. Menciptakan suasana akademik yang kondusif, meningkatkan atusias siswa dalam menciptakan sebuah solusi dan ide kreatifitas yang luas tanpa batas tentunya didukung oleh teknologi yang sesuai dengan bidang keahlian. Menciptakan lulusan yang berkompeten, mampu beradaptasi dengan lingkungan, khususnya kemajuan teknologi, membawa kecerdasan bangsa semakin meningkat dan maju berwawasan global. Teknologi memiliki peranan yang sangat penting bagi pendidikan dalam memberikan wawasan dan pengetahuan dalam penerapan keilmuan, penelitian dan pengabdian kemasyarakatan, melalui penerapan pengaplikasian sesuai bidang keilmuan yang menghasilkan luaran yang berguna bagi masyarakat dan bangsa. Pendidikan dasar desain memiliki potansi yang luas didalam mengembangkan metode dan teknik sebagai terapan aplikasi pembelajaran yang mutakhir, beradaptasi terhadap kemajuan teknologi demi kemajuan bangsa.

\section{DAFTAR PUSTAKA}

[1] Undang-undang Republik Indonesia nomor 20 Tahun 2003 Tentang SISDIKNAS (Bandung: Citra Umbara. 2006), 72

[2] Adib, Mohammad. (2011). Filsafat ilmu: onto-logi, epistemologi, aksiologi, dan logika ilmu pengetahuan. Yogyakarta: Pustaka Pelajar

[3] Aziz A. (2018). Education 4.0 Made Simple: Ideas For Teaching. International Journal of Education \& Literacy Studies. Akademi Pengajian Bahasa, Universiti Teknologi MARA (UiTM) Diakses 13 Agustus 2019

[4] Bachtiar, Amsal. (2012). Filsafat ilmu edisi revisi. Jakarta: Raja Grafindo Persada.

[5] Buhal. (2000). Visi Iptek memasuki milenium III. Jakarta: UI Press.

[6] Daymon, C., \& Holloway, I. (2007). Metode-Metode Riset Kualitatif dalam Public Relations dan Marketing Communications. Bentang Pustaka.

[7] Diwan, P. (2017). Is Education 4.0 an imperative for success of 4th Industrial Revolution?

[8] Dr. Asfi Manzalati, S. M. (2017). Metodologi Penelitian Kualitatif, Paradigma, Metode, dan Aplikasi. Malang: Universitas Brawijaya Media.

[9] Dwiningrum, S. I. A. (2012). Ilmu sosial \& budaya dasar. Yogyakarta: UNY Press

[10] Echnical Education and Skills Development Authority. 2016. Technological Change is Coming: The Fourth Industrial Revolution.

[11] Eka I Putu, Elis K, Ika L, Sukrata I K. Rani G. (2017). Peran Teknologi dan Media dalam Belajar. Media desiminasi tugas mahasiswa Pascasarjana Institut Hindu Dharma Negeri Denpasar.

[12] Hariwijaya, M. (2017). Metodologi dan Teknik Penulisan Skripsi, Tesis \& Disertasi: Elmatera. Diandra Kreatif

[13] Himittshuqalbu. (2011, November 3). Metode Eksperimen Retrieved Agustus 8, 2018, from Eksperimen, Matematika, Materi Kuliah, Metode Pembelajaran.

[14] Martono, Nanang. (2012). Sosiologi perubahan sosial: perspektif klasik, modern, postmodern, dan postkolonial. Jakarta: PT. Raja Grafindo Persada. 
Jhon Viter Marpaung

Penerapan Konsep Pembelajaran Industri 4.0 pada Pendidikan Dasar Desain

[15] Muhamad Ngafifi, 2014, Kemajuan Teknologi dan Pola Hidup Manusia dalam Perspektif Sosial Budaya.
[16] Risdianto E. (2019). Analisis Pendidikan Indonesia Diera Revolusi Industri 4.0. 